\title{
The Musical Glamour in Pasternak’s Poetry
}

\author{
Yaqin Liu \\ School of Foreign Languages \\ Inner Mongolia University for the Nationlities \\ Tongliao, Inner Mongolia, China \\ e-mail: 1269487503@qq.com
}

\begin{abstract}
Pasternak gets into the literary world by poetry creation and is regarded as a dazzling new star in twentieth century Russian literature. Study of his poetry works has made significant achievements in the past few decades. His poetry works systematically describe his unique poetic world. This paper aims at analyzing the musical Glamour embodied in Pasternak's poetry in the aspects of the blending of poetry and music as well as the connection between Pasternak and music.
\end{abstract}

Keywords—poetry; music; Pasternak

\section{INTRODUCTION}

In 1958, Pasternak was awarded the Nobel Literary Prize for "his outstanding achievements in the fields of modern lyric poetry and the great Russian narrative literature", and had since become a dazzling star in the twentieth century Russian literature. Study of his poetry works has made significant achievements in the past few decades. His poetry works systematically describe his unique poetic world. Pasternak connects closely with music in his musical quality and early creation. He gets poetry and reality subtly combined with highly pure notes. His superb writing skills gain profound respect and his poetry embodies beating notes and beautiful melody.

\section{THE BLENDING OF POETRY AND MUSIC}

Poetry and music are two different forms of art, which produce works involving the subjects from aesthetic intention to artistic image, from emotion to artistic conception in different expression and creation forms. Poetry is regarded as the art language of highest class and it shows writers' real feelings in vivid, lively, simple and fluent language, bringing people into a realm of beauty. Music reflects people's inner world by the beating notes. The beautiful melody can arouse people the imagination of the inner vision image, offering people full aesthetic enjoyment and happiness. Poetry and music are mutually promoted, complemented, influenced and blended. The meaning of "poetry" in itself contains the feature of "music". The feature of blending involved in the absorption of music by poetry is unreachable by other literature forms. Poetry and music are so closely blended that it brings great aesthetic pleasure to people. When the language rhythm of poetry, the rhythm of music, human physiology and state of mind are in harmony, it can arouse resonance and emotions. The musical quality of poetry is not only displayed in the aspect of language rhythm, but also the sense. Poetry conveys human thoughts and feelings and the involvement of musical elements makes such expression more powerful and perfect. The blending of poetry and music makes it a mixed art which is viewed as a miracle in the world of literature and even the history of world music. The unique musical beauty of his poetry comes from his music quality and deep understanding of music.

\section{THE CONNECTION BETWEEN PASTERNAK AND MUSIC}

Pasternak's unique talent for music comes from the influence of his upper-class statues and family. On the one hand, the aristocratic education in Russia required musical understanding ability and creation ability of the children of nobles. School offered a variety of musical education which fostered children's aristocratic temperament; On the other hand, genetic factors and postnatal cultivation enabled him to achieve considerable attainments in the field of music. Pasternak's father was a painter who had created many famous works of painting and he compiled illustrations for Tolstoy's novel Resurrection. His mother was a musician, a student of famous music master Rubenstein. At a very young age, Pasternak had a special perceiving ability of music and sensitive reaction to music. As he recalled:

"As I remember clearly that one night I was waken up by a sweet, charming pain. Before this, I had never had such feeling. I cried out in agony and fear, crying. But tears were overwhelmed by music. When that trio music which woke me up finished, my crying was finally heard...... Why would I cry, why until today I still remember the pain?..... the sound of the string, especially the one played indoor is very harsh to me, which disturbs me as if that's the crying for help and bad news coming from the ventilation [115-6]"

At the age of six, Pasternak began to learn music and attended family concerts of high society frequently. The famous musician Scriabin, once the neighbor of his, personally guided him. He developed the unique ability to appreciate music when he was six. His profound perception of Scriabin's Third Symphony "Sacred Poetry" was amazing:

"Oh God, what kind of music it is! Like a city suffered from artillery bombardment which continuously collapses and dumps, symphony is piled up by the ruins. The music is full of new content with crazy processing, just like the growing woods imbued with life and freshness...... The music he composed is of a tragic force. It sniffs at everything which is corrupted but praised, great yet very stupid. It is bold to the 
degree of arrogance. It is childish, just like a dissolute angel, naïve and naughty but free."

He was frantic about music and had professional teachers and music critics to instruct him. However, as he had "no absolute hearing ability", Pasternak who originally should have become a musician had to switch to philosophy. The painful decision of giving up the music was recorded in his memoirs:

"I've spent six years of painstaking efforts on music. Music is a world full of hope and unease, but I have to bid farewell to the most precious thing in my heart. There was once a period of time when I was accustomed to playing fantasy on the piano, but such faults have also been gradually fading away. Later, I decided to take decisive measures to constrain myself. I no longer touched the piano nor attended the concert and even avoided meeting musicians......" [1]20

\section{HIS INFATUATION FOR MUSIC IS HARD TO PART WITH}

Although Pasternak gave up his dream of becoming a musician, his complex for music was hard to part with. Music had always been part of his life. During the period of him studying in Moscow State University and university of Marburg, he often attended concerts and recited his poetry in the party several times. He seemed to find the rhythms of poetry in the music and the beauty of music in the poetry. The early works of Pasternak were influenced by the Symbolist poets. Obscure words, complex intention, uncommon ancient words, rare geographical names, rhetoric, syntactics, line folding, intervals, punctuations and symbols had become special codes, which were like the beating notes in music, making the soul of the poetry dance subsequently. When we get to listen to Pasternak's poetry as music, we will be attracted by the natural and smooth features, which helps us to know more about Pasternak and approach his art world.

Many of Pasternak's early works are influenced by music. His second collection of poetry "Over the Barricade" which symbolizes his entry into the literary circle was once named the "Forty-four Etudes"; "Safe Conduct" is an autobiographical essay in his early life. It describes the far-reaching meeting with Rilke, listening to the teaching of the musician Scriabin. The poet is like playing a undulate tune on the piano which brings the music into the heart and life of the people; " My Sister Life" completed in 1918 won the praise of many writers and critics such as Mandelstam, Tsvetayeva and Boyusof. This collection of poems had brought great honor to him, therefore laid his position as a modern Russian poet. This poem was composed as a song for many times and widely sung by people; "Noble Disease" utilizes internal rhyme, double rhythm and even multiple rhythm to increase the rhythm and melody of it; four volumes of poetry " Themes and Variations " was written completely in accordance with the creation method of music. There were many famous musicians who were closely related to him in his life and creation. Among them, Tchaikovsky enlightened him in music and his third symphony influenced him; Scriabin had led him into the palace of music; the world famous pianist Neuhaus was his friend. Music had become something indispensable to his life. It was involved in each poem of his and worked as the reflection of the beauty of his poetry. A poet who can turn the music into poetry not only benefited from his internal strength of music, but also the education by the masters of music.

\section{THE AESTHETIC REFLECTION EMBODIED IN THE UNITY OF POETRY, MUSIC AND EMOTION}

Pasternak's early writing is mainly about the human fate, love and natural scenery. It is unique in writing style, ingenious in conception, accurate in wording, which is deep and subtle with fresh metaphor. Pasternak uses the writing technique of symbolism to integrate people's inner mind with natural scenery ingeniously. He expresses the exclamation of life and death, the expression of love, the local customs and social conditions in the language of poetry. His intent endows the poem with more sense of mystery and obscurity, leading readers to explore and taste.

"My Sister Life" is his representative work of symbolism in his early years. This collection is the elaborate combination of poetry, reality, and highly pure notes. The strong contrast, subtle tonal effects, flexible and accurate metaphor blend the nature and human beings. The writing skills of this Russian allrounder poet in the turbulent period of Russian history deserve profound respect from people.

My sister - Life's overflowing today,

spring rain shattering itself like glass,

but people with monocles still complain,

and sting, politely, like snakes in the wheat field.

The elders have their logic of course, certainly yours is foolish, no doubt: that eyes and lawns glow lilac in storms, and sweet perfume of mignonette blows from the south.

That in May, when traveling you see the timetable on the Kamyshin line, the Bible's penned no less magnificently, while in reading it you're mesmerised.

That sunset has only to show a village, girls crowding the track as we flee, and I find that it's not my stop today, the sunset offering its sympathy.

With three splashes the bell swims by,

'Sorry, not here': its apology's far.

Burning night seeps under the blind,

the steppe plunges, forming ladder to star. 
Winking, blinking, sweetly somewhere,

my love, a fata-morgana, sleeps yet,

while, like my heart, splashed on platforms there,

the carriage throws window-light over the steppe.

\section{Written in Summer of 1917}

In the poem, the rich and colorful natural scenery is reflected in poetry in the form of color, sound and smell. The rhetoric means such as contrast, metaphor, synaesthesia and association make the sentence more devious and implicit. This poem highlights Pasternak's early writing talents. He said in a commentary: "I reject the traditional poetic image based on similarity. He believed that common image makes reading too easy. He proposed a rhetoric principle of metonymy which is used to substitute the name of an attribute or feature for the name of the thing itself". Mandelstam thought that he "is not the inventor nor wizard, but a founder of a new model---a new Russian poetry structure which makes the language more mature and dynamic ". The fact that this poem was composed the tune, widely sung in Russians and maintained the enduring charm and won the popularity of the masses even after many years was inseparable from the content of daily life and lively music.

February. Take ink and weep......February. Take ink and weep! Write February as you're sobbing, while black spring burns deep through the slush and throbbing. Take a cab. For a clutch of copecks, through bell-towers' and wheel noise, go where the rain-storm's din breaks, greater than crying or ink employs. Where rooks in thousands falling like charred pears from the skies, drop down into puddles, bringing cold grief to the depths of eyes. Below, the black shows through, and the wind's furrowed with cries: the more freely, the more truly, then, sobbing verse is realised.

Pasternak said: "Writing is as speaking in that the music is never just from sound. It is not out of the coordination of vowels and consonants, but rather depends on the relationship between speech and meaning. Meaning and content are always the priority". [21 This poem is the representative work in Pasternak's symbolism period, which describes the shift of seasons, the expression of feelings, ink and mud, crying corresponding with rolling. The hues of rooks, bursts of shouting of wind, choked cry, crackling of the fallen raindrop, those sounds (cry, rain and water etc.) are depicted by the author with the use of verbs to develop the whole poem. "Music" used in poetry greatly increases the expressive force of poetry itself. The uncertain feelings and the melody of rich connotation display thought-provoking conception, arousing readers' feeling and generating their empathy. Pasternak put the music into poetry and the reality into the hearts.

Throughout Pasternak's creation road, although language has experienced the development from being dim, and obscure to being clear and simple, on the whole the lyric has one's own knack in art, which integrates art and music into the natural scenery depiction, describes the character's mind activity, thoughts and emotions incisively, just like a beautiful and subtle picture or a classical music, provoking a fresh feeling.
The ingenious combination of poetry and music, as well as the use of vocabulary and grammar structure, on the one hand, are thanks to art nurturing of family; on the other hand, are due to the influence by the Symbolist poet Blok et al as he joined in "Lyric" symbolism poetry group. of course, this is also due to the frenetic love for music embedded in his inner world, which has great influence on his future poetry creation. The early poetry contains intention from being explicit to being implicit. He combined vision and hearing by implication and synaesthesia, creating a kind of extreme beauty. He often used obscure words such as the ancient words, names and so on in order to enhance the rhythm of poetry, forming different sound effects. Pasternak had a unique talent for poetry which occupies a prominent position in the history of Russian literature. His works greatly enrich the poetry culture of modern Russian. The influence of German poet Rainer Maria Rilke, Lev Tolstoy, Scriabin has decisive significance for his later creation. The poetry of Pasternak is equally picturesque music.

\section{REFERENCES}

[1] Pasternak, Boris. translated by Wulanhan. Essay in Autobiography [M]. 2012, 5-6,15-16,20.

[2] Beidao. The Description of Pasternak. www.docin.com

[3] Zhang Juemin. Thirsty Years, the Local Nature of Farmers' Paintings [N].Chinese Culture,2009-01-05. 